\title{
IMPLEMENTASI UML PADA SISTEM PENJADWALAN MATA KULIAH
}

\author{
Rudy Ansari ${ }^{1)}$, Nahdi Subairi ${ }^{2)}$ \\ ${ }^{1,2)}$ Program Studi Informatika Fakultas Teknik Universitas Muhammadiyah Banjarmasin \\ Jl.Gubernur Syarkawi, Handil Bakti, Barito Kuala \\ e-mail: rudy@umbjm.ac.id ${ }^{1)}$, nahdi@umbjm.co.id ${ }^{2)}$
}

\begin{abstract}
ABSTRAK
Dalam penjadwalan mata kuliah memerlukan sistem otomatis agar penjadwalan dapat efektif dan efesien. Agar sistem efektif dan efesien maka diperlukan penerapan algoritma yang cukup handal. Dengan perancanga sistem menggunakan Unified Modeling Language (UML) bertujuan untuk memahami kompleksitas desain dari sistem, kami memodelkan pendekatan menggunakan usecase dan squence diagram. Usecase dan Squence diagram adalah diagram UML paling penting yang digunakan untuk pengembangan aplikasi perangkat lunak. Ada banyak properti yang harus dipertimbangkan saat menggambar usecase dan squence diagram. Kedua diagram ini mewakili berbagai aspek aplikasi perangkat lunak. Hasil dari model yang diusulkan telah ditemukan bermanfaat ketika diimplementasikan.
\end{abstract}

Kata Kunci: UML, penjadwalan, usecase, squence diagram.

\begin{abstract}
In scheduling courses ask for an automatic system so that scheduling can be effective and efficient. In order for the system to be effective and efficient an algorithm application that is quite reliable is needed. By designing the system using the Unified Modeling Language (UML) to facilitate the design updates of the system, we model the approach using usecase and squence diagrams. Usecase and Squence diagrams are the most important UML diagrams used for software application development. There are many properties that must be enjoyed when drawing usecase and squence diagrams. This second diagram represents various aspects of software applications. The results of the approved model have been found to be useful compilations implemented.
\end{abstract}

Keywords: UML, scheduling, usecase, sequence diagram.

\section{PENDAHULUAN}

$\mathrm{P}$ endekatan metode Unified Modeling Language (UML) pada desain dari sistem penjadwalan mata kuliah ini digunakan karena UML menggunakan Unified Modeling Language (UML). UML adalah bahasa notasi untuk keperluan umum dalam menentukan dan memvisualisasikan sistem yang kompleks, terutama untuk proyek-proyek besar berbasis berorientasi objek[1]. UML membantu komunikasi antara semua pemangku kepentingan dalam proses Life Cycle perangkat lunak. Dalam membuat sistem penjadwalan mata kuliah digunakan diagram usecase dan sequence diagram.

\section{UML}

Unified modelling language (UML) adalah bahasa grafis untuk memvisualisasikan, menentukan, membangun, dan mendokumentasikan sistem intensif perangkat lunak [2], [3]. UML menyediakan cara standar untuk menulis blue print sistem, mencakup hal-hal konseptual, kelas yang ditulis dalam bahasa pemrograman tertentu, skema database, dan komponen perangkat lunak yang dapat digunakan kembali. UML adalah notasi standar yang digunakan oleh siapa saja yang terlibat dalam produksi, penyebaran, dan pemeliharaan perangkat lunak [4],[5],[6]. UML mencakup sembilan diagram untuk menggambarkan sistem.

\section{DESAIN UML}

Perancangan sistem dalam sistem ini menggunakan teknik analisis data dalam pembuatan perangkat lunak menggunakan UML. UML (Unified Modeling Language) adalah bahasa pemodelan untuk sistem atau perangkat lunak yang berparadigma OOP (Object Oriented Programming) [7]. Pada perancangan sistem informasi penjadwalan mata kuliah ini ruang lingkup yang akan dibuat untuk hak akses dalam sistem terbagi berdasarkan user levelnya yaitu sebagai berikut:

1) Admin tingkat Fakultas atau UPT sebagai super admin memiliki lebih banyak hak akses pada sistem yaitu mengelola program studi (prodi) beserta user prodi, log user, ruang perkuliahan, tahun ajaran, reset password user, ubah password, penjadwalan, perubahan jadwal perkuliahan, dan cetak jadwal.

2) Admin Prodi sebagai user memiliki beberapa hak akses meliputi mengelola data mata kuliah, dosen, daftar mata kuliah, jumlah peserta, ubah password, reset password dan cetak jadwal.

3) Pimpinan sebagai user hanya memiliki akses untuk melihat jadwal, mengkonfirmasi atau menyetujui jadwal 
perkuliahan yang telah disusun admin, ubah password dan cetak jadwal.

4) Dosen sebagai user hanya memiliki akses melihat jadwal perkuliahan, mengunduh jadwal, request perubahan jadwal, ubah password dan melihat notification perubahan jadwal.

5) Guest yang meliputi mahasiswa dan pengunjung website tidak memiliki hak akses untuk login melainkan hanya dapat melihat jadwal perkuliahan, pengumuman perubahan jadwal dan mengunduh jadwal perkuliahan.

Diagram yang digunakan dalam analisa pemodelan yaitu, usecase diagram dan activity diagram. Berikut perancangan sistem dengan menggunakan UML.

\section{A. Usecase Diagram}

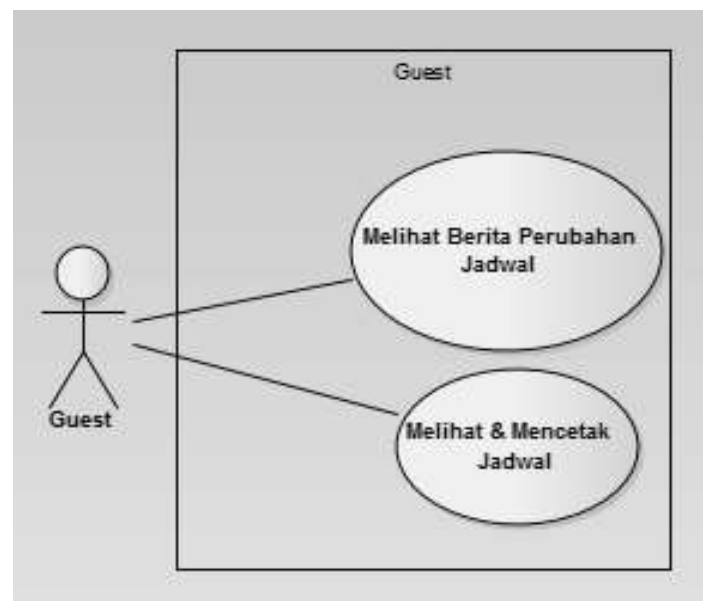

Gambar. 1. Usecase Diagram Untuk Guest

\section{1) Usecase Diagram Untuk Guest}

Pada usecase diagram untuk guest, saat pertama kali mengakses halaman utama sistem informasi penjadwalan mata kuliah, guest dapat melihat jadwal perkuliahan, melihat pengumuman perubahan jadwal perkuliahan dan mengunduh jadwal. Untuk guest pada usecase ini meliputi mahasiswa dan pengunjung website. Adapun gambaran usecase diagram untuk guest yang akan dibuat ini dapat dilihat seperti pada Gambar 1 berikut.

\section{2) Usecase Diagram Untuk Admin Fakultas}

Pada usecase diagram untuk admin Fakultas, saat pertama kali admin Fakultas mengakses halaman utama, admin Fakultas dapat melakukan beberapa pengelolaan data yang meliputi mengelola data user prodi, mengelola data prodi, mengelola data tahun ajaran, mengelola data ruangan, mengelola data penjadwalan, mengelola perubahan jadwal, ubah dan reset password, dan logout. Adapun gambaran usecase diagram untuk admin fakultas yang akan dibuat ini dapat dilihat seperti pada Gambar 2

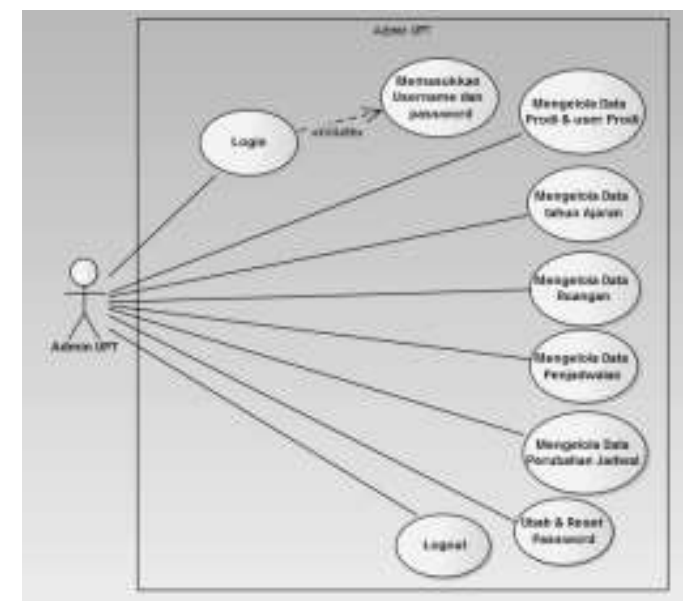

Gambar. 2. Usecase Diagram Untuk Admin Fakultas 


\section{3) Usecase Diagram Untuk Admin Prodi}

Pada usecase diagram untuk admin prodi, saat pertama kali admin prodi mengakses halaman utama, admin prodi dapat melakukan beberapa pengelolaan data juga yang meliputi mengelola data mata kuliah, mengelola data dosen, mengelola data daftar mata kuliah, melihat dan cetak jadwal mengelola jumlah peserta, ubah dan reset password dan logout. Data daftar mata kuliah ini meliputi kode mata kuliah, nama mata kuliah, sks, dosen dan nama prodi. Adapun gambaran usecase diagram untuk admin prodi yang akan dibuat ini dapat dilihat seperti pada Gambar 2

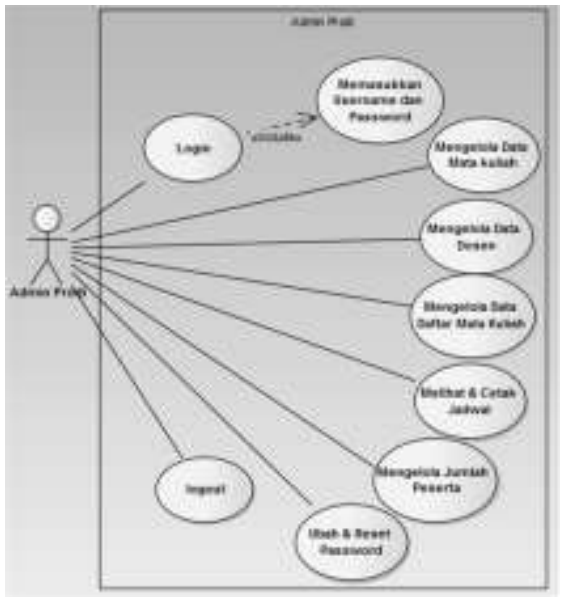

Gambar. 3. Usecase Diagram Untuk Admin Prodi

\section{4) Usecase Diagram Untuk Pimpinan}

Pada usecase diagram untuk Pimpinan yang dipegang oleh Wakil Dekan 1 saat mengakses sistem informasi penjadwalan mata kuliah ini, Pimpinan dapat melihat jadwal, konfirmasi jadwal dan cetak jadwal, ubah password dan logout. Adapun gambaran usecase diagram untuk Wakil Dekan 1 yang akan dibuat ini dapat dilihat seperti pada Gambar 4.

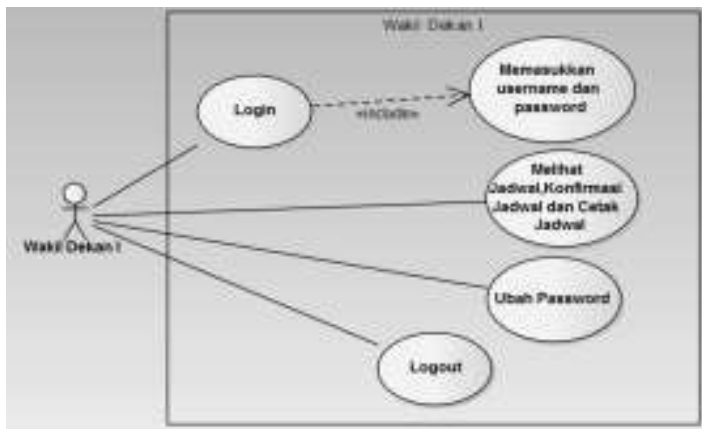

Gambar. 4. Usecase Diagram Untuk Kepala Prodi

\section{5) Usecase Diagram Untuk Dosen}

Pada usecase diagram untuk dosen saat mengakses sistem informasi penjadwalan ini, dosen dapat melihat jadwal dan unduh jadwal, request perubahan jadwal, melihat notification perubahan jadwal, ubah password dan logout. Adapun gambaran usecase diagram untuk dosen yang akan dibuat ini dapat dilihat seperti pada Gambar 5.

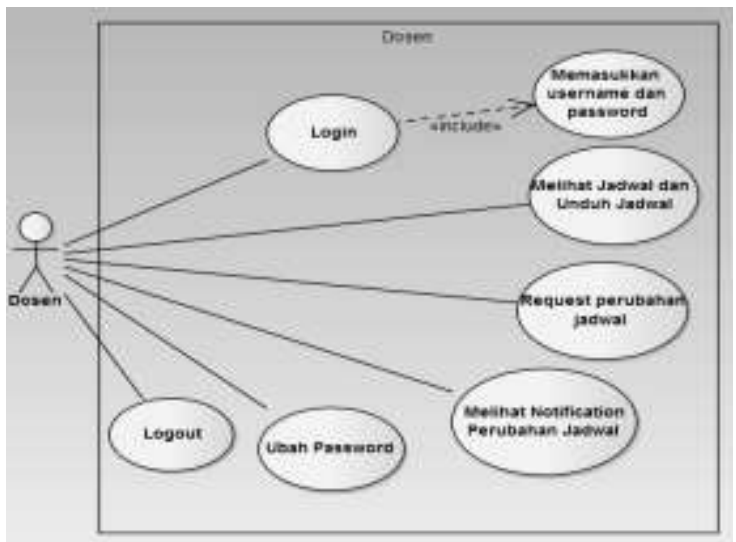




\section{B. Activity Diagram}

\section{1) Activity Diagram Sistem yang Akan Dibuat}

Pada analisa sistem yang akan dibuat dalam proses pembuatan jadwal perkuliahan alur sistem dimulai dari admin Fakultas yang mengelola data prodi, tahun ajaran dan ruangan selanjutnya prodi menginputkan data mata kuliah, data dosen dan daftar mata kuliah yang meliputi kode mata kuliah, nama mata kuliah, sks, dosen dan nama prodi. Selanjutnya data daftar mata kuliah tersebut diproses oleh admin Fakultas untuk di generate secara otomatis dengan Algoritma Genetika.

Dalam proses pengelolaan penjadwalan dengan metode algoritma genetika ini untuk jadwal di generate secara otomatis untuk mendapatkan jadwal yang tidak bentrok. Setelah di generate secara otomatis oleh sistem, admin Fakultas akan mendapatkan data daftar mata kuliah, ruangan dan waktu yang meliputi hari dan jam perkuliahan, Selanjutnya masing-masing prodi akan menginputkan jumlah peserta mata kuliah. Setelah itu prodi menginputkan jumlah peserta per mata kuliah dari masing-masing prodinya, pada proses ini terdapat pengambilan keputusan (decision) jika jumlah peserta yang diinputkan telah sesuai dengan kapasitas ruangan maka akan menghasilkan jadwal perkuliahan tetapi apabila jumlah peserta melebihi kapasitas ruangan yang tersedia terdapat dua aksi yaitu pindah ruangan/tambah kelas.

. Selanjutnya jadwal perkuliahan yang telah dihasilkan dari proses generate ini akan dilihat oleh Wakil Dekan I untuk disetujui, setelah jadwal disetujui, baru kemudian jadwal tersebut dipublikasikan di website sistem informasi penjadwalan dan manajemen ruang perkuliahan yang dapat diakses oleh guest dan dosen untuk melihat jadwal perkuliahan dan proses pun berakhir.

Adapun gambaran dari proses ini dapat dilihat pada proses alur sistem seperti pada Gambar 6.

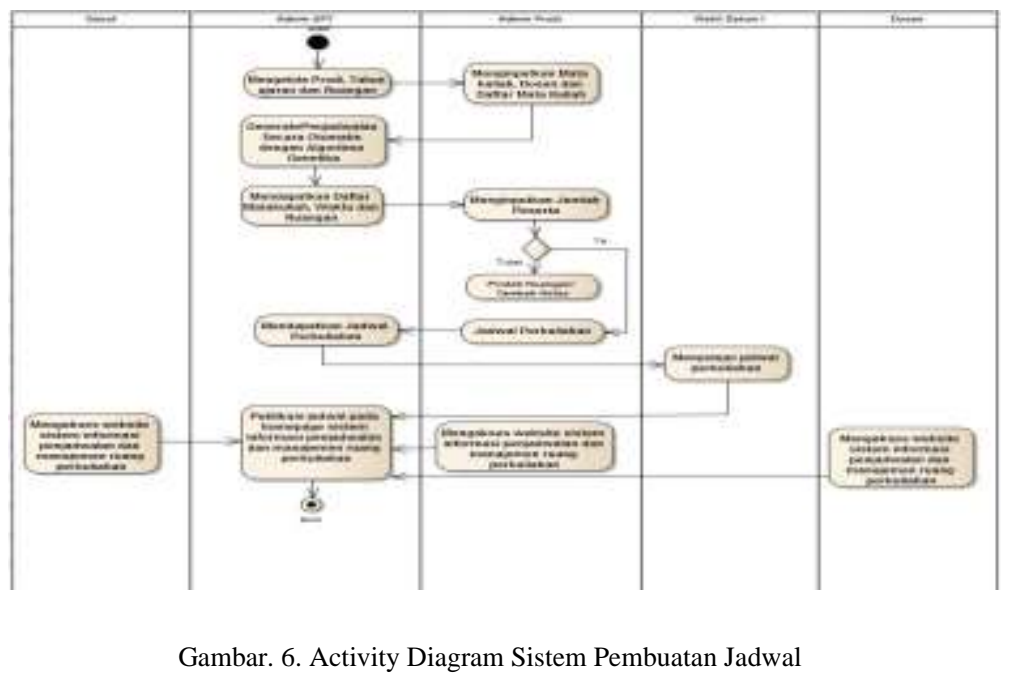

\section{2) Activity Diagram Perubahan jadwal Pada Sistem}

Pada activity diagram perubahan jadwal pada sistem informasi penjadwalan dan manajemen ruang perkuliahan ini proses dimulai dari dosen yang ingin merubah jadwal perkuliahan sementara, dosen harus melakukan login ke sistem informasi penjadwalan dan melakukan request perubahan jadwal perkuliahan sementara kemudian admin Fakultas akan menerima notification request perubahan jadwal sementara dari dosen tersebut, selanjutnya admin Fakultas akan memeriksa jadwal kosong pada sistem informasi penjadwalan. Pada proses ini terdapat pengambilan keputusan (decision) jika ada jadwal kosong maka admin UPT akan menampilkan berita perubahan jadwal sementara pada homepage sistem informasi penjadwalan, tapi apabila tidak ada maka admin Fakultas akan memberikan notifikasi untuk dosen jadwal kosong yang tersedia dan dosen yang bersangkutan dapat memilih sesuai jadwal kosong yang tersedia, untuk selanjutnya admin Fakultas akan konfirmasi request dan menampilkan berita perubahan jadwal sementara tersebut pada homepage sistem informasi penjadwalan dan proses pun berakhir.

Adapun gambaran dari activity diagram sistem perubahan jadwal perkuliahan sementara dapat dilihat seperti pada Gambar 7. 


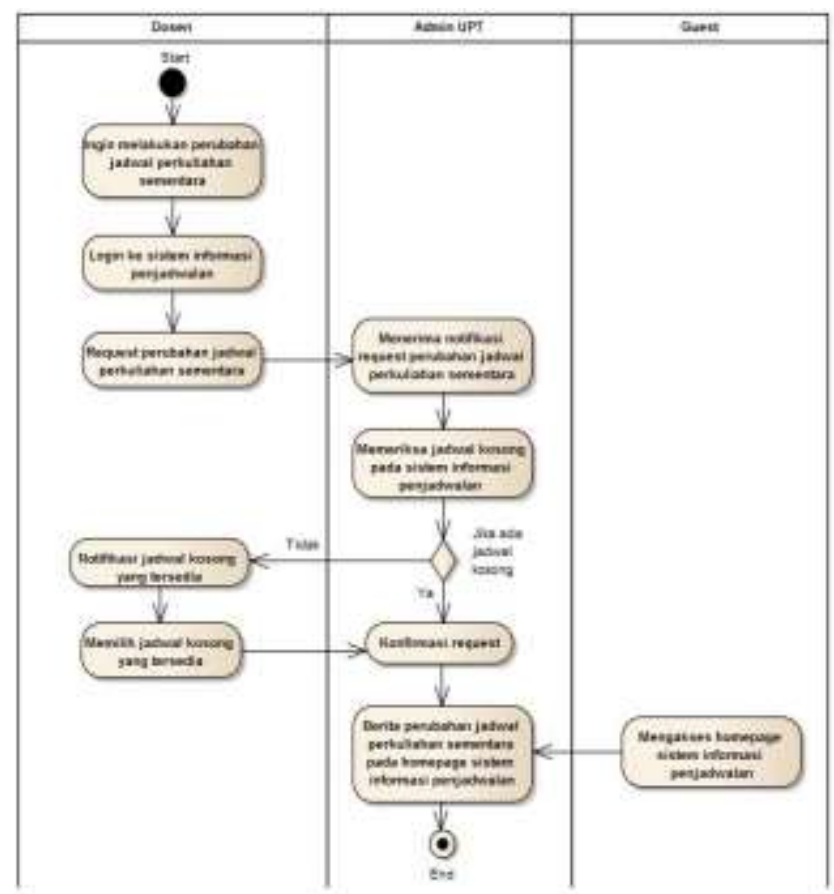

Gambar. 7. Activity Diagram Sistem Perubahan Jadwal

\section{3) Activity Diagram Guest}

Pada activity diagram guest sistem informasi penjadwalan dan manajemen ruang perkuliahan saat halaman ini diakses guest, website akan menampilkan halaman beranda yang berisi berita perubahan jadwal perkuliahan, selain itu terdapat menu jadwal untuk melihat informasi jadwal perkuliahan atau mencetak jadwal. Adapun gambaran activity diagram homepage yang akan dibuat ini dapat dilihat seperti pada Gambar 8.

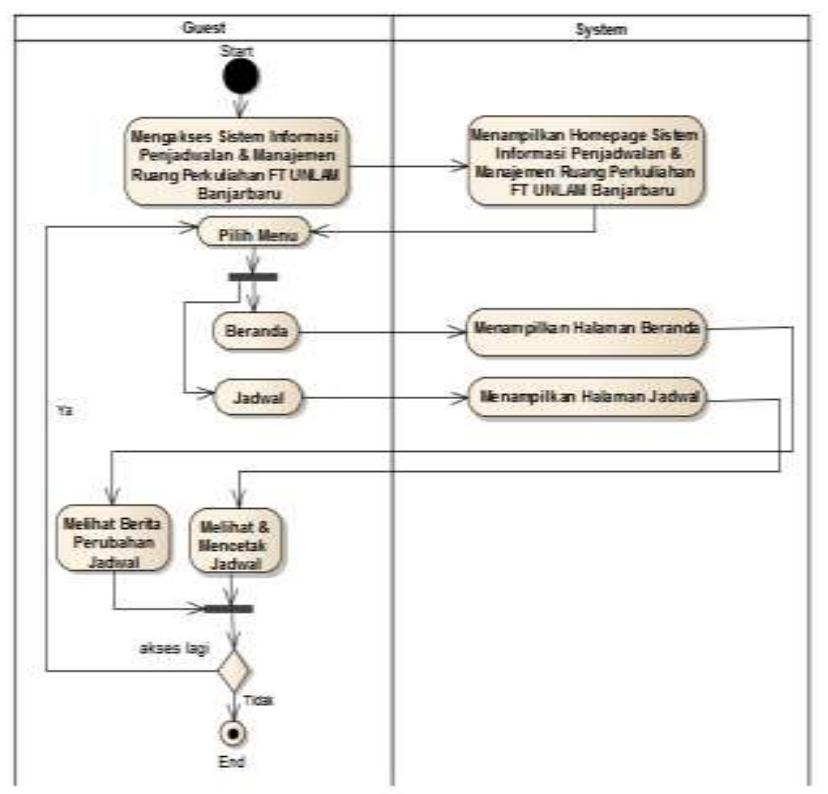

Gambar. 8. Activity Diagram Guest 


\section{4) Activity Diagram Admin Fakultas}

Pada activity diagram halaman admin Fakultas atau UPT ini dimulai dengan masuk ke halaman login, admin Fakultas harus memasukkan username dan password untuk dapat mengakses menu utama. Jika username dan password yang dimasukan tidak benar atau salah maka akan diminta untuk memasukan ulang username dan password yang benar. Jika username dan password yang dimasukan sudah benar maka sistem akan memvalidasi untuk dapat masuk ke halaman menu utama admin Fakultas yang berisi menu prodi, menu tahun ajaran, menu ruangan, menu penjadwalan, menu perubahan jadwal dan menu ubah password. Untuk setiap menu yang dipilih sistem akan menampilkan halaman sesuai menu yang dipilih. Pada menu prodi, admin Fakultas dapat mengelola data prodi dan mengelola data user masing-masing prodi, untuk menu tahun ajaran dan menu ruangan, menu ini untuk mengelola data tahun ajaran dan data ruangan. sedangkan pada menu penjadwalan merupakan menu untuk admin Fakultas mengelola penjadwalan dengan mengenerate otomatis jadwal perkuliahan dengan algoritma genetika, melihat jadwal dan mencetaknya dan pada menu ini juga admin Fakultas dapat memeriksa ruangan kosong yang tersedia. Untuk menu perubahan jadwal selain untuk mengelola perubahan jadwal, pada menu ini admin UPT dapat melihat notification dari dosen yang melakukan request perubahan jadwal dan pada menu ubah password ini terdapat dua aksi yaitu untuk merubah password admin Fakultas dan reset password untuk mereset semua password user. Untuk setiap proses mengelola data, maka data akan disimpan atau diambil dari database, Selanjutnya untuk keluar dari halaman admin Fakultas maka pilih menu logout dan aktivitas pun berakhir sedangkan untuk kembali mengelola data maka proses akan kembali ke pilih menu. Gambaran dari sistem activity diagram untuk halaman admin Fakultas atau UPT ini dapat dilihat seperti pada Gambar 9.

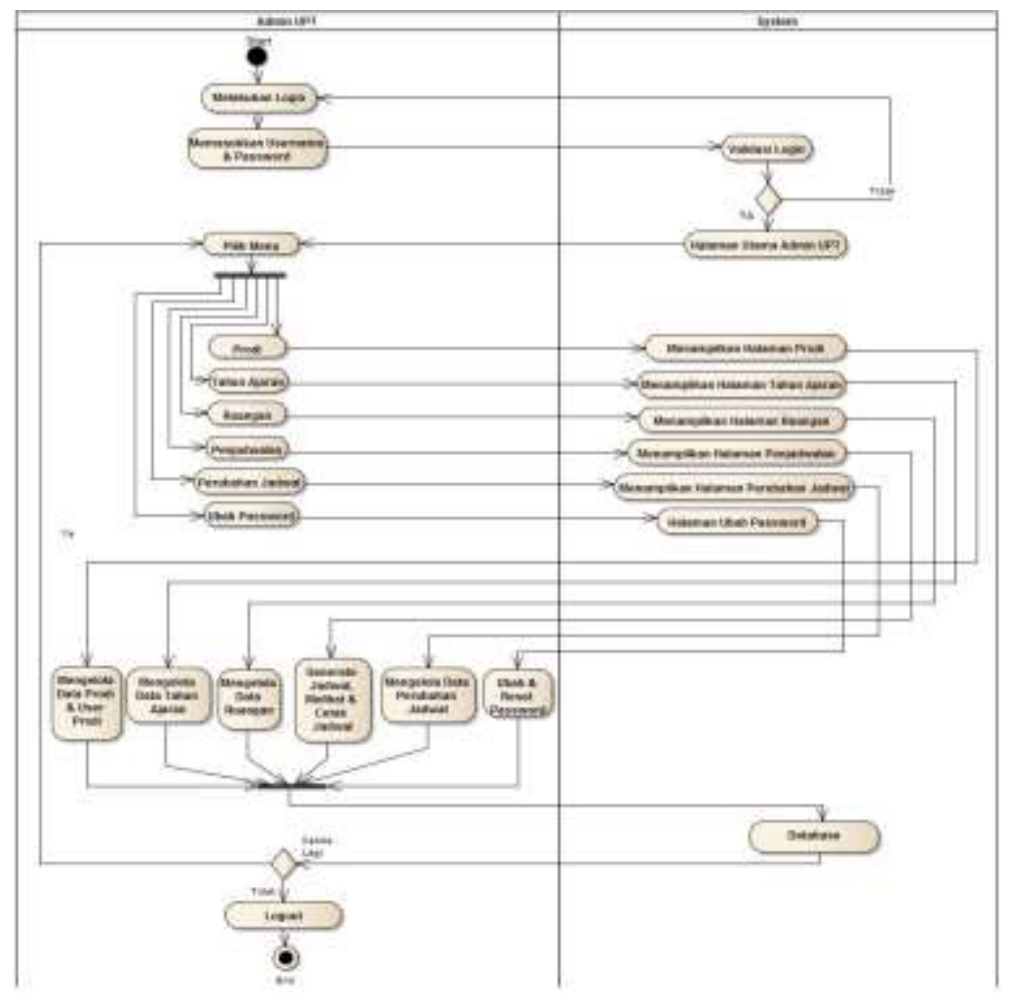

Gambar. 9. Activity Diagram Admin Fakultas atau UPT

\section{5) Activity Diagram Admin Prodi}

Pada activity diagram halaman admin prodi ini dimulai dengan masuk ke halaman login, admin prodi harus memasukkan username dan password untuk dapat mengakses menu utama. Jika username dan password yang dimasukan tidak benar atau salah maka akan diminta untuk memasukan ulang username dan password yang benar. Jika username dan password yang dimasukan sudah benar maka sistem akan memvalidasi untuk dapat masuk ke halaman menu utama admin prodi yang berisi menu mata kuliah, menu dosen, menu daftar mata kuliah, menu jadwal, menu jumlah peserta dan menu ubah password. Untuk setiap menu yang dipilih sistem akan menampilkan halaman sesuai menu yang dipilih. Pada menu mata kuliah admin prodi dapat mengelola data mata kuliah yang meliputi nama mata kuliah, kode mata kuliah dan sks. Untuk menu dosen, menu ini untuk mengelola data dosen dan menu daftar mata kuliah 
untuk mengelola daftar mata kuliah yang meliputi data mata kuliah, dosen dan nama prodi.

Sedangkan pada menu jadwal admin prodi dapat melihat jadwal dan cetak jadwal dan untuk menu jumlah peserta admin dapat mengelola jumlah peserta perkuliahan. Pada menu ubah password terdapat dua aksi yaitu untuk merubah password admin prodi dan reset password untuk mereset password dosen. Untuk setiap proses mengelola data, maka data akan disimpan atau diambil dari database. Selanjutnya untuk keluar dari halaman admin prodi maka pilih logout dan aktivitas pun berakhir sedangkan untuk kembali mengelola data maka proses akan kembali ke pilih menu. Gambaran dari sistem activity diagram untuk halaman admin prodi ini dapat dilihat seperti pada Gambar 10.

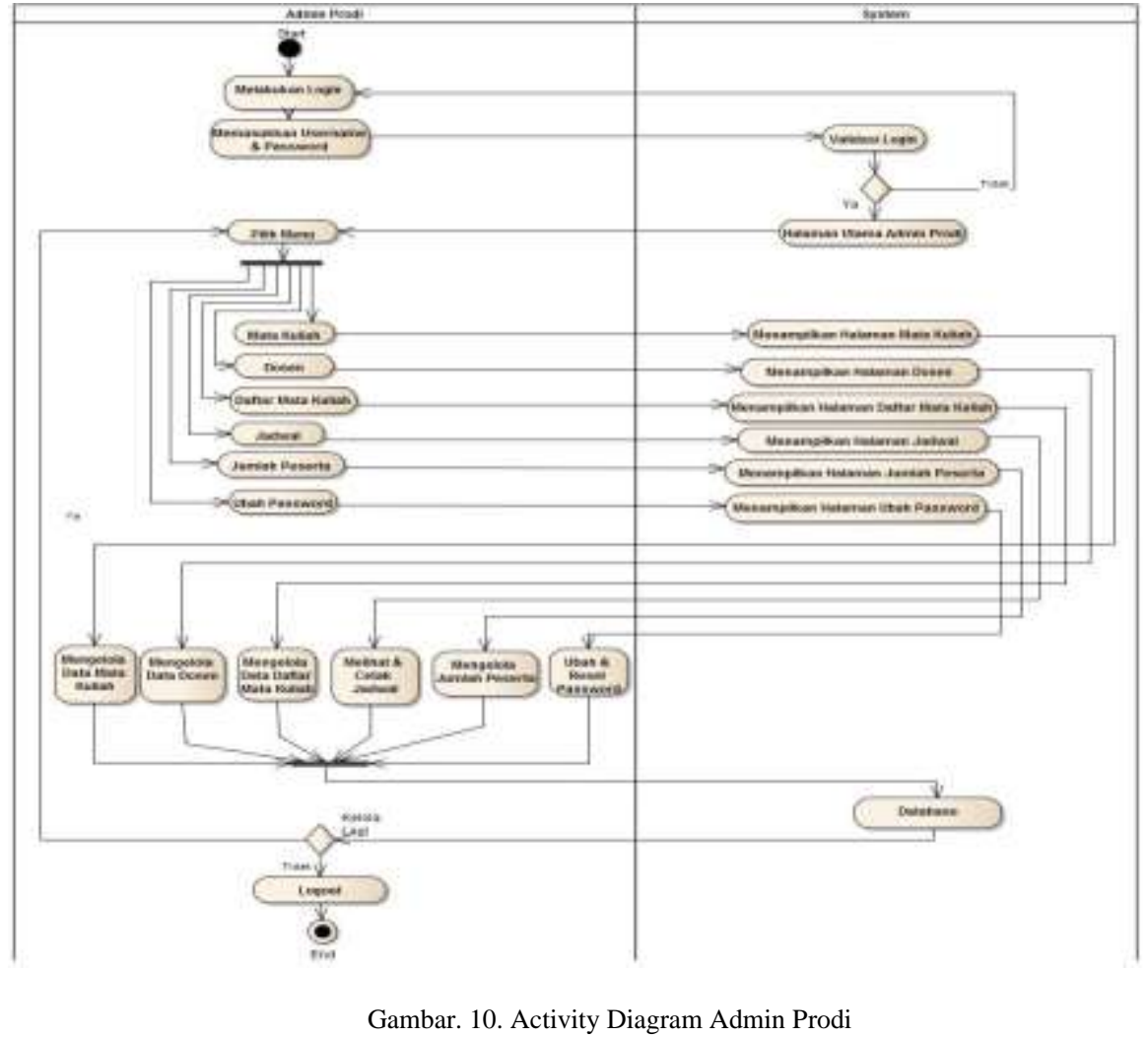

\section{6) Activity Diagram Pimpinan}

Pada activity diagram halaman Wakil Dekan I ini, dimulai dengan masuk ke halaman login, Wakil Dekan I harus memasukkan username dan password untuk dapat mengakses menu utama. Jika username dan password yang dimasukan tidak benar atau salah maka akan diminta untuk memasukan ulang username dan password yang benar. Jika username dan password yang dimasukan sudah benar maka sistem akan memvalidasi untuk dapat masuk ke halaman menu utama yang berisi menu konfirmasi jadwal dan menu ubah password. Untuk setiap menu yang dipilih sistem akan menampilkan halaman sesuai menu yang dipilih. Pada menu konfirmasi jadwal Wakil Dekan I dapat melihat jadwal, menyetujui jadwal yang telah di generate oleh admin UPT dan mencetaknya. Untuk menu ubah password untuk merubah password. Untuk proses konfirmasi jadwal dan ubah password data akan disimpan atau diambil dari database. Selanjutnya untuk keluar dari halaman ini maka pilih menu logout dan aktivitas pun berakhir, tetapi jika ingin kembali mengakses maka proses akan kembali ke pilih menu. Gambaran dari sistem activity diagram untuk halaman Wakil Dekan I ini dapat dilihat seperti pada Gambar 11. 


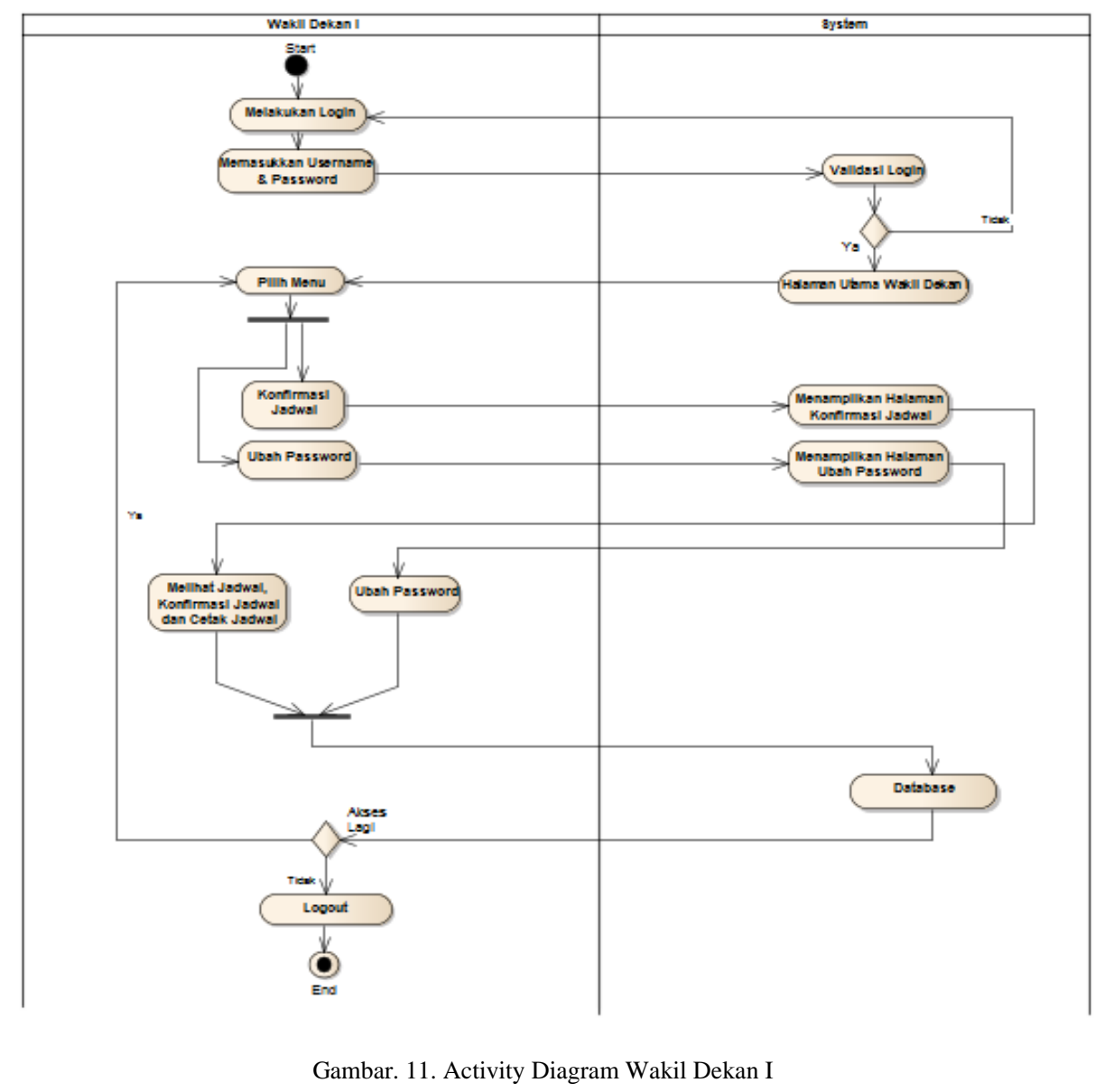

\section{7) Activity Diagram Dosen}

Pada activity diagram dosen ini proses dimulai dengan masuk ke halaman login, dosen harus memasukkan username dan password untuk dapat mengakses menu utama. Jika username dan password yang dimasukan tidak benar atau salah maka akan diminta untuk memasukan ulang username dan password yang benar. Jika username dan password yang dimasukan sudah benar maka sistem akan memvalidasi untuk dapat masuk ke halaman menu utama dosen yang berisi menu jadwal, menu request, menu notification dan menu ubah password. Untuk setiap menu yang dipilih sistem akan menampilkan halaman sesuai menu yang dipilih. Pada menu jadwal dosen dapat melihat dan mengunduh jadwal, untuk menu request dosen dapat melakukan request perubahan jadwal, untuk menu notification berisi pemberitahuan hasil request perubahan jadwal ke admin UPT dan untuk menu ubah password untuk merubah password.

Untuk proses dalam menu jadwal, menu request, menu notification dan menu ubah password data disimpan atau diambil dari database. Selanjutnya untuk keluar dari halaman ini maka pilih menu logout dan aktivitas pun berakhir, tetapi apabila ingin kembali mengakses proses akan kembali ke pilih menu. Gambaran dari sistem activity diagram untuk halaman dosen ini dapat dilihat seperti pada Gambar 11. 


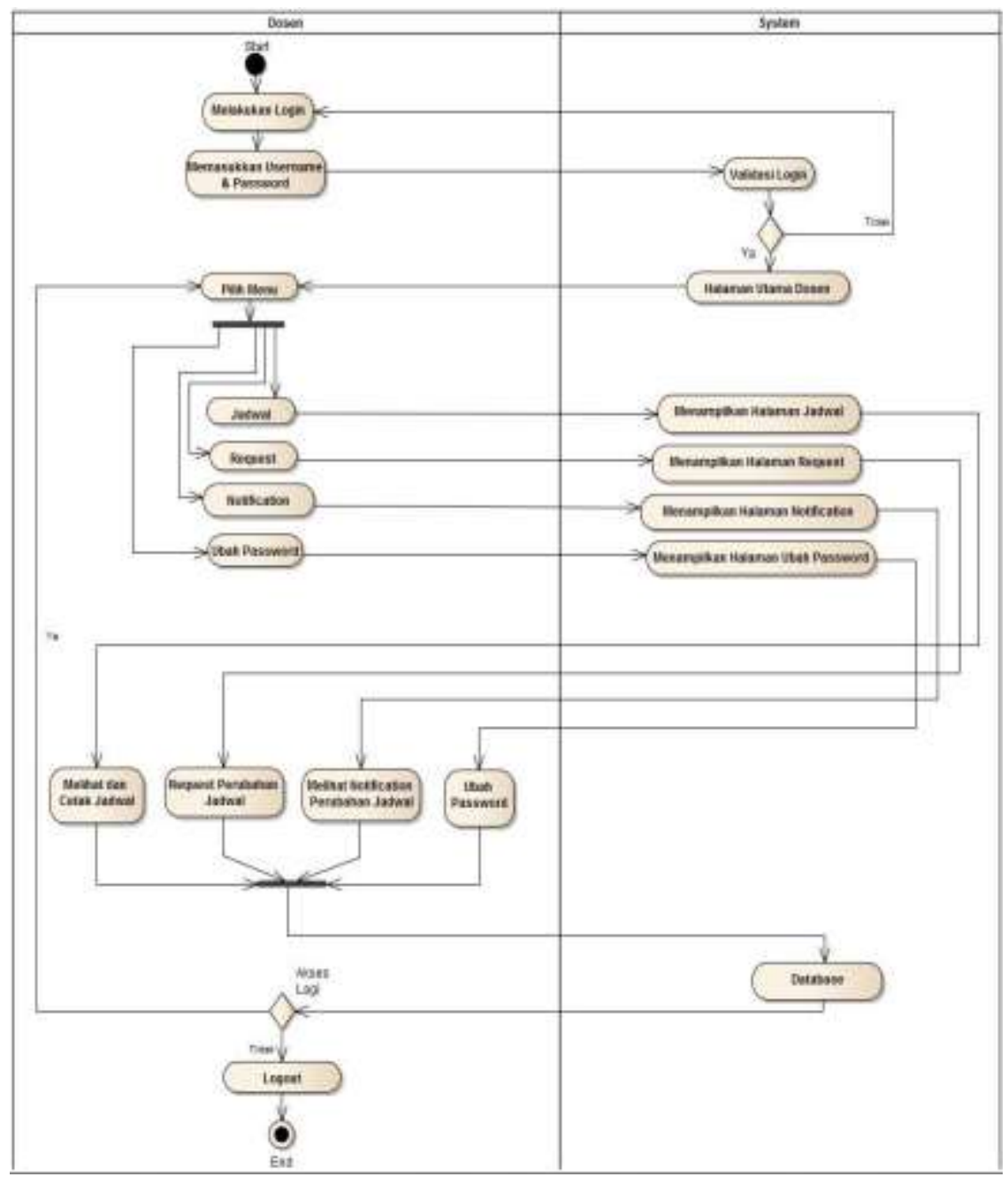

Gambar. 12. Activity Diagram Dosen

\section{KESIMPULAN}

UML mampu mendeskripsikan sistem secara baik kepada semua pemangku kepentingan yang terlibat pada sistem penjadwalan mata kuliah ini. Usecase diagram terdiri dari 5 diagram yaitu: usecase diagram untuk admin prodi, admin fakultas, guest atau mahasiswa, dosen dan pimpinan. Sedangkan activity diagram sebanyak 7 diagram yaitu: activity diagram pembuatan jadwal, perubahan jadwal, guest, admin prodi, admin fakultas, pimpinan dan dosen. Hasil dari model UML ini sangat bermanfaat dalam tahap implementasi sitem.

\section{DAFTAR PUSTAKA}

[1] A. Kaur, “Application Of UML In Real-Time Embedded Systems,” Int. J. Softw. Eng. Appl., vol. 3, no. 2, pp. 59-70, 2012.

[2] B. Padmanabhan, "Unified Modeling Language (UML) Overview.," EECS810 - Princ. Softw. Eng., 2012.

[3] Y. Sari and I. Prasetia, "SISTEM INFORMASI MANAJEMEN BERBASIS UML ( STUDI KASUS PEMELIHARAAN TOILET PADA KAMPUS FAKULTAS TEKNIK UNIVERSITAS LAMBUNG MANGKURAT ),” JTIULM, pp. 1-6, 2016.

[4] S. Ahmad and V. Saxena, "Design of formal air traffic control system through UML," Ubiquitous Comput. Commun. J., vol. 3, no. 6, pp. 11-20, 2008.

[5] S. Mauluddin, L. Paris, and A. Sahata, "Automation Lecture Scheduling Information Services through the Email Auto-Reply Application," Int. J. Adv. Comput. Sci. Appl., vol. 9, no. 12, pp. 291-297, 2019.

[6] Y. Sari, A. Muhtarom, Q. L. H. T. T. Nguyen, P. T. Nguyen, and Ansir, "Predictors of job performance: Moderating role of conscientiousness," Int. J. Innov. Creat. Chang., vol. 11, no. 6, pp. 135-152, 2020.

[7] A. Dennis, B. H. Wixom, and R. M. Roth, System Analysis \& Design, 5th ed. Amerika Serikat, 2012. 
JTIULM - Volume 05, Nomor 1, April 2020: 1 - 10 